\title{
EFEKTIVITAS REHABILITASI TERHADAP PELAKU PENYALAHGUNAAN NARKOBA \\ (STUDI DI BADAN NARKOTIKA NASIONAL KOTA CIREBON) Oleh: Virgiawan Listianto ${ }^{1}$
}

\begin{abstract}
Drug use is a crime that has brought about victims of drug use in the community. Ideally, narcotics are required in the world of health and science, but in the same time the use of illegal narcotics is a very dangerous one, so that legal devices aimed at controlling the distribution and use of such addictive substances are indispensable.

The method of approach used in this research is a qualitative method with a sociological juridical approach (Sosio-legal research). The specification of this research is descriptive according to the problems and objectives in this research. Primary data sources and secondary data sources and are analyzed in a qualitative method.

The efforts to implement rehabilitation conducted by the Government against narcotics users pursuant to article 54 Juncto Article 55 Act number 35 year 2009 about narcotics is doing various measures to prevent narcotic abuse, by means of rehabilitation can help the victims, rehabilitation there are two: medical rehabilitation and social rehabilitation, and counseling.

Keywords: effectivity, rehabilitation, manipulation

\section{Abstrak}

Penyalagunaan narkoba merupakan suatu tindak pidana yang telah memunculkan korban-korban penyalagunaan narkotika dalam masyarakat. Secara ideal, narkotika diperlukan dalam dunia kesehatan dan ilmu pengetahuan akan tetapi secara bersamaan penggunaan narkotika yang bersifat melawan hukum merupakan suatu yang sangat berbahaya, sehingga perangkat hukum yang bertujuan untuk mengontrol peredaran dan penggunaan zat adiktif tersebut sangat diperlukan.

Metode pendekatan yang dipergunakan dalam penelitian ini adalah metode kualitatif dengan pendekatan yuridis sosiologis (sosio-legal research). Spesifikasi penelitian ini bersifat deskriptif sesuai dengan masalah dan tujuan dalam penelitian ini. Sumber data primer dan Sumber data sekunder serta dianalisis secara metode kualitatif.

Upaya penerapan rehabilitasi dilakukan oleh Pemerintah terhadap pengguna narkotika berdasarkan Pasal 54 Juncto Pasal 55 Undang-Undang Nomor 35 Tahun 2009 Tentang Narkotika adalah dengan melakukan berbagai tindakan guna mencegah penyalahgunaan narkotika, dengan cara rehabilitasi lebih dapat membantu para korban, rehabilitasi ada dua yaitu: rehabilitasi medis dan rehabilitasi sosial, dan konseling Kata kunci: efektifitas, rehabilitasi, penyalahgunaan.
\end{abstract}

\footnotetext{
${ }^{1}$ Advocat, Indramayu
} 


\section{A. Latar Belakang}

Penyalahgunaan dan peredaran gelap narkotika merupakan permasalahan yang membutuhkan perhatian khusus dari kita semua. Bukan hanya penegak hukum tetapi juga masyarakat. Narkotika digunakan secara terbatas pada dunia kedokteran, namun belakangan terjadi penyimpangan fungsi dan penggunaannya. Secara ideal, narkotika diperlukan dalam dunia kesehatan dan ilmu pengetahuan akan tetapi secara bersamaan penggunaan narkotika yang bersifat melawan hukum merupakan suatu yang sangat berbahaya, sehhingga perangkat hukum yang bertujuan untuk emngontrol peredaran dan penggunaan zat adiktif tersebut sangat diperlukan. ${ }^{2}$

Penyalagunaan narkoba merupakan suatu tindak pidana yang telah memunculkan korban-korban penyalagunaan narkotika dalam masyarakat. Korban penyalaguaan narkotika diatur dalam UndangUndang Nomor 35 tahun 2009 tentang narkotika, yang mana dalam hal ini penyalagunaan narkotika di bagi menjadi dua yaitu pecandu narkotika dan korban penyalagunaan

${ }^{2}$ Muntaha. Aspek Yuridis Penyalahgunaan Narkotika di kalangan Remaja. Jurnal Mimbar Hukum, Vol. 23 Nomor 1 Februari 2011, Yogyakarta: Fakultas Hukum Universitas Gadjah Mada, hlm. 216. narkotika. Pecandu narkotika adalah orang yang menggunakan atau menyalagunakan narkotika dan dalam keadaan ketergantungan pada narkotika, baik secara fisik maupun psikis. $^{3}$ Sedangkan penyalaguna adalah orang yang menggunakan narkotika tanpa hak atau melawan hukum. ${ }^{4}$

Upaya penanggulangan narkotika yang dilakukan untuk mengurangi jumlah penyalahgunaan narkotika tidaklah cukup dengan satu cara, melainkan harus dilaksanakan dengan rangkaian tindakan yang berkesinambungan dari berbagai macam unsur, baik dari lembaga pemerintah maupun non pemerintah. Rangkaian tindakan tersebut mencakup usaha-usaha yang bersifat preventif, represif dan rehabilitative.

Penetapan rehabailitasi bagi pecandu narkotika merupakan pidana alternatif yang dijatuhkan oleh hakim dan diperhitungkan sebagai masa menjalani hukuman dan juga diatur di dalam Undang-Undang No. 35 tahun 2009 tentang Narkotika. Ketentuan hukum yang mengatur mengenai rehabilitasi terhadap pecandu narkotika diatur dalam Pasal 54, Pasal 56, Pasal 103 dan dikaitkan dengan Pasal 127 Undang-

\footnotetext{
${ }^{3}$ Pasal 1 butir 13 Undang-Undang No. 35 tahun 2019 tentang Narkotika. Jakarta: Sinar Grafika, hlm.5. ${ }^{4}$ Ibid., hlm. 6.
} 


\section{1 | Jurnal Idea Hukum}

VoI. $6 \mathrm{No} .2$ Oktober 2020

Magister Hukum Universitas Jenderal Soedirman

Undang No. 35 tahun 2009 tentang Narkotika. Dari hal ini, yang menarik dalam Pasal 103 yaitu dalam pasal tersebut memberikan kewengnangan kepada hakim untuk menjatuhkan vonis/sanksi bagi seseorang yang terbukti sebagai pecandu narkotika untuk menjalani rehabilitasi. $^{5}$

Berdasarkan Pasal 103

Undang-Undang No. 35 tahun 2009 tentang narkotika menyebutkan hakim yang memeriksa perkara pecandu narkotika dapat melakukan dua hal, yaitu pertama, hakim dapat memutuskan untuk memerintahkan yang bersangkutan menjalani pengobatan dan/atau perawatan apabila pecandu narkotika tersebut bersalah melakukan tindak pidana narkotika. Kedua, hakim dapat menetapkan untuk memerintahkan yang bersangkutan menjalani pengobatan dan/atau perwatan apabila pecandu narkotika tersebut tidak terbukti bersalah melakukan tindak pidana narkotika. Secara tersirat kewenangan ini mengakui bahwa korban penyalahgunaan narkotika selain sebagai pelaku tindak pidana juga sekaligus korban dari kejahatan itu sendiri yang dalam sudut viktimologi kerap disebut

5 Didik M. Arief Mansur dan Elisatris Gultom. 2007. Urgensi Perlindungan Korban Kejahatan. Jakarta: PT. Raja Grafindo Persada, hlm. 89. dengan self victimazation atau victimeless crime. ${ }^{6}$

Sebagian besar narapidana atau tahanan kasus narkotika adalah pemakai sekaligus sebagai korban jika dilihat dari aspek kesehatan yang sesungguhnya orang-orang tersebut menderita sakit akibat pemakaian narkotika tersebut, sehingga dengan memberikan sanksi pidana penjara bukanlah langkah yang tepat untuk dilakukan. Perkembangan hukum narkotika dan psikotropika di Indonesia secara historis, diawali dengan perkembangan peredaran narkotika, yang diatur dalam verdovende middelen ordonnantie (staatsblad Nomor 278 jo Nomor 536).

Dalam kehidupan masyarakat, aturan ini lebih dikenal dengan sebutan Peraturan obat bius. Peraturan perundang-undangan ini, materi hukumnya hanya mengatur mengenai perdagangan dan penggunaan narkotika, sedangkan tentang pemberian pelayanan kesehatan untuk usaha penyembuhan pecanduannya tidak diatur. $^{7}$

Narkotika merupakan zat atau obat yang sangat bermanfaat dan diperlukan untuk pengobatan penyakit tertentu. Namun, jika

\footnotetext{
${ }^{6}$ Ibid., hlm. 100.

7 Siswanto. 2012. Politik Hukum dalam Undang-Undang Narkotika. Jakarta: Rineka Cipta, hlm. 5 .
} 
disalahgunakan atau digunakan tidak sesuai dengan standar pengobatan dapat menimbulkan akibat yang sangat merugikan bagi perseorangan atau masyarakat khususnya generasi muda. Hal ini akan lebih merugikan jika disertai dengan penyalahgunaan dan peredaran gelap Narkotika yang dapat mengakibatkan bahaya yang lebih besar bagi kehidupan dan nilainilai budaya bangsa yang pada akhirnya akan dapat melemahkan ketahanan nasional. $^{8}$

Dampak dari penyalahgunaan narkotika adalah dapat berakibat pada pengguna itu sendiri dan pada masyarakat pada umumnya. Bagi individu akan membawa dampak yang merugikan bagi kesehatan baik kesehatan rohani maupun jasmani. Sedangkan bagi masyarakat akan berdampak kemerosotan moral dan meningkatnya kriminalitas. ${ }^{9}$

Peraturan bersama tentang penanganan narkotika dan korban penyalahgunaan narkotika telah diatur ke dalam Lembaga Rehabilitasi yang dikeluarkan oleh Kepala Badan Narkotika Nasional Republik yakni Peraturan bersama Nomor PERBER/01/III/2014/BNN. ${ }^{10}$

Badan Narkotika Nasional (BNN) adalah sebuah Lembaga

8 Penjelasan Undang-Undang Republik Indonesia Nomor 35 tentang Narkotika.

9 Soedjono Dirdjosisworo. 1987. Hukum Narkotika Indonesia. Bandung: Alumni, hlm. 25.

${ }^{10}$ M. Taufik Makarao. 2003. Tindak Pidana Narkotika. Jakarta: Ghalia Indonesia, hlm. 34.
Pemerintah Non Kementerian (LPNK) Indonesia yang mempunyai tugas melaksanakan tugas pemerintahan di bidang pencegahan, pemberantasan penyalahgunaan dan peredaran gelap psikotropika, prekursor dan bahan adiktif lainnya kecuali badan adiktif untuk tembakau dan alokohol. Dasar hukum Badan Narkotika Nasional adalah UndangUndang Nomor 35 tahun 2009 tentang Narkotika. Sebelumnya Badan Narkotika Nasional merupakan lembaga nonstrukstur yang dibentuk berdasarkan Keputusan Presiden Nomor 17 tahun 2002 yang kemudian diganti dengan Peraturan Presiden Nomor 83 tahun 2007.

Badan Narkotika Nasional (BNN) diberi kewenangan untuk melakukan penyelidikan dan penyidikan yang mana dalam hal ini belum diatur dalam undang-undang yang lama. Dua kewenangan dirasa perlu untuk mengantisipasi kejahatan narkotika dengan modus operandi yang semakin kompleks dan didukung oleh jaringan organisasi. Tidak hanya penambahan kewenangan, status kelembagaan Badan Narkotika Nasional pun ditingkatkan. ${ }^{11}$

Undang-undang Nomor 35 tahun 2009 tentang narkotika telah

${ }^{11}$ Anonim. Peraturan Presiden Republik Indonesia Nomor 23 tahun 2010 tentang Badan Narkotika Nasional. 
33 | Jurnal Idea Hukum

Vol. $6 \mathrm{No} .2$ Oktober 2020

Magister Hukum Universitas Jenderal Soedirman

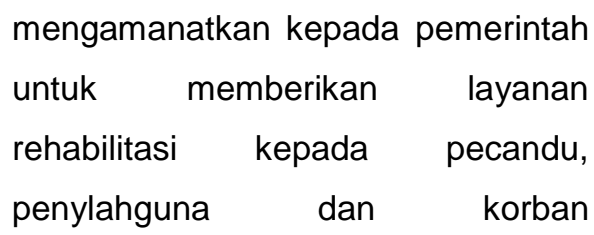
penyalahgunaan narkotika serta para orang tua untuk melaporkan anaknya yang pecandu narkoba, penyalahguna atau korban penyalahguna narkoba kepada Institusi Penerima Wajib Lapor yang berada di Puskesmas, Rumah Sakit Pemerintah dan poliklinik BNN. ${ }^{12}$

Efektivitas berlakunya undangundang ini sangatlah tergantung pada seluruh jajaran penegak hukum, yang dalam hal ini seluruh instansi yang terkait langsung, yakni Badan Narkotika Nasional serta para penegak hukum yang lainnya. Disisi lain, hal yang sangat penting adalah perlu adanya kesadaran hukum dari seluruh lapisan masyarakat guna menegakan kewibawaan hukum dan khususnya terhadap UndangUndang Nomor 35 tahun 2009 tentang narkotika.

Rehabilitasi adalah adalah yang baik bagi proses penyembuhan baik pelaku ataupun korban penyalahgunaan narkotika serta sebagai langkah penting dalam menyelamatkan para pecandu dari belenggu narkotika dan obat-obatan terlarang. Vonis rehabilitasi berlaku

${ }^{12}$ Badan Narkotika Nasional Republik Indonesia. 2013. Rehabilitasi dan Penindakan Hukum harus menjadi Panglima. Http://bnn.go.id., diakses 30 September 2018, Pukul 21.41 WIB. bagi pengguna narkoba yang tertangkap tangan sebagaimana yang diatur dalam Surat Edaran Mahkamah Agung (SEMA) Nomor 3 tahun 2011 dan SEMA Nomor 4 tahun 2010 yang berisi himbauan kepada para hakim untuk tidak memenjarakan pecandu narkoba melainkan memasukan mereka ke dalam lembaga rehabilitasi. ${ }^{13}$

\section{B. Metode Penelitian Hukum}

Metode pendekatan yang dipergunakan dalam penelitian ini adalah metode kualitatif dengan pendekatan yuridis sosiologis (sosiolegal research). Menurut Soerjono Sukanto bahwa penelitian hukum sosiologis atau empiris yang mencakup penelitian terhadap identifikasi hukum (tidak tertulis) dan penelitian terhadap efektifitas hukum. $^{14}$ Spesifikasi penelitian ini bersifat deskriptif sesuai dengan masalah dan tujuan dalam penelitian ini. $^{15}$ Lokasi penelitian dilakukan di Badan Narkotika Nasional kota Cirebon. Sumber data primer yaitu data yang langsung dikumpulkan oleh peneliti (atau petugasnya) dari sumber pertamanya. Data primer merupakan data yang bersumber

\footnotetext{
13 Zoraya Ralie. 2017. Tahapan dan Proses Raehabilitasi Penyalahgunaan Narkoba. Http://www.google.com., 30 September 2018, Pukul 20.00 WIB.

${ }^{14}$ Soerjono Sukanto. 2010. Pengantar Peneliti Hukum. Jakarta: UII Pres, hlm. 15.

${ }^{15}$ Soerjono Sukanto. 1986. Penelitian Hukum. Jakarta: Universitas indonesia, hlm. 25.
} 
dari pendapat langsung oleh narasumber. Sumber data sekunder yaitu data yang langsung dikumpulkan oleh peneliti sebagai penunjang dari sumber pertama. Data Primer. ${ }^{16}$ Analisis data dalam penelitian ini menggunakan metode kualitatif.

\section{Pembahasan}

\section{a. Bentuk Upaya Rehabilitasi Badan Narkotika Nasional Terhadap Pelaku Penyalahgunaan Narkoba Kota Cirebon.}

Undang-Undang Nomor 35 Tahun 2009 tentang Narkotika dirancang untuk menekan jumlah peredaran narkotika di Indonesia yang telah bersifat transnasional dan untuk mengurangi jumlah korban penyalahgunaan narkotika terutama di kalangan remaja yang membahayakan kehidupan masyarakat. Hal ini dapat dilihat dalam konsideran UndangUndang Nomor 35 Tahun 2009 tentang Narkotika. Dengan tujuan untuk mengurangi jumlah korban penyalahgunaan narkotika tersebut maka dalam UndangUndang Nomor 35 Tahun 2009 tentang Narkotika dibuatkan bab khusus yaitu dalam Bab IX yang mencantumkan mengenai

${ }^{16}$ Sugiyono. 2008. Memahami Penelitian Kualitatif. Bandung: Alfabeta, hlm. 74.

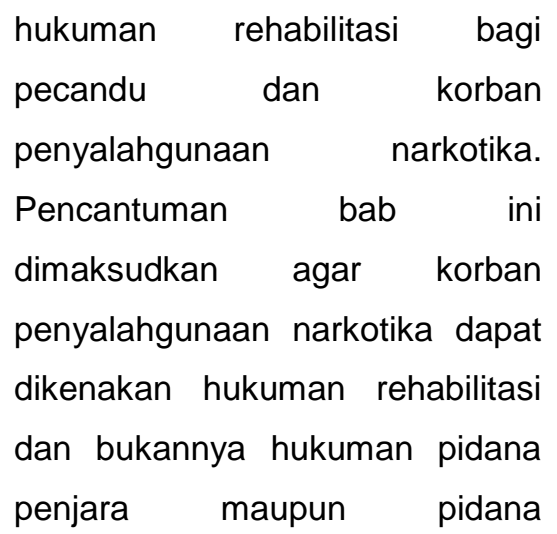
kurungan.

Untuk mencapai penyembuhan para korban penyalahgunaan narkotika dari ketergantungan tersebut, maka hukuman yang sepatutnya diberikan kepada mereka adalah pembinaan dan rehabilitasi. Hukuman pembinaan dan rehabilitasi ini telah diatur dalam Pasal 54, dan Pasal 103 UndangUndang Nomor 35 Tahun 2009 tentang Narkotika, serta diatur juga dalam SEMA Nomor 7 Tahun 2009 tentang Menempatkan Pemakai Narkotika ke Dalam Panti Terapi dan Rehabilitasi, serta SEMA Nomor 4 Tahun 2010 tentang Penempatan Penyalahgunaan, Korban Penyalahgunaan dan Pecandu Narkotika ke Dalam Lembaga Rehabilitasi Medis dan Rehabilitasi Sosial. Pasal 54 dan Pasal 103 merumuskan bahwa:

\section{Pasal 54}

Pecandu Narkotika dan korban penyalahgunaan narkotika wajib 
35 | Jurnal Idea Hukum

Vol. $6 \mathrm{No} .2$ Oktober 2020

Magister Hukum Universitas Jenderal Soedirman

menjalani rehabilitasi medis dan rehabilitasi sosial.

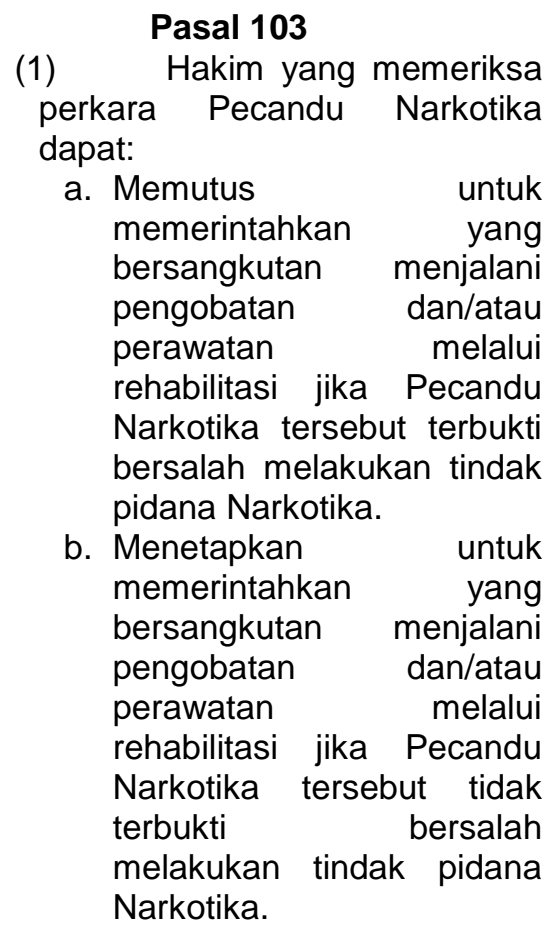

(2) Masa menjalani pengobatan dan/atau perawatan bagi Pecandu Narkotika sebagaimana dimaksud pada ayat (1) huruf a diperhitunngkan sebagai masa menja0lani hukuman.

Penggunaan rehabilitasi dianggap lebih dapat membantu para korban penyalahgunaan narkotika daripada penjatuhan pidana penjara atau pidana kurungan. Penjatuhan rehabilitasi ini sesuai dengan Surat Edaran Mahkamah Agung Nomor 04 Tahun 2010 tentang Menempatkan Pemakai Narkotika kedalam Panti Terapi dan Rehabilitasi yang menyatakan bahwa mereka sebagai tahanan kasus narkotika sesungguhnya orang yang sakit sehingga tindakan rehabilitasi hendaknya lebih tepat dijatuhkan dan kondisi LAPAS

(Lembaga Pemasyarakatan) yang tidak mendukung dikhawatirkan malah mengakibatkan efek yang tidak baik terhadap mereka karena dapat semakin memperburuk kesehatan serta kondisi kejiwaan para penyalah guna narkotika tersebut. Penyalahgunaan narkotika adalah penggunaan yang dilakukan tidak untuk maksud pengobatan, tetapi karena ingin menikmati pengaruhnya, dalam jumlah berlebih, kurang teratur, dan berlangsung cukup lama, sehingga menyebabkan gangguan kesehatan fisik, mental dan kehidupan sosial. ${ }^{17}$

Benny J. Mamoto, Direktur Narkotika Alami BNN berpendapat mengenai perubahan yang ada pada Undang-Undang Nomor 35 Tahun 2009 ini, ia mengatakan programprogram BNN mengacu pada Undamg-Undang Nomor 35 Tahun 2009. Jika sebelumnya para penyalahguna diperlakukan sebagai kriminal, hanya tangkaptahan-proses-masuk Lembaga Pemasyarakatan (LP). Namun,

\footnotetext{
17 Badan Narkotika Nasional. 2009. Pencegahan
} Penyalahgunaan Narkoba Sejak Dini. Jakarta, hlm. 36. 


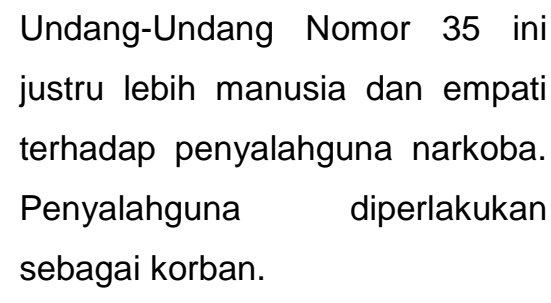

Penanganan dalam melakukan upaya dilakukannya rehabilitasi terhadap pelaku tindak pidana penyalahgunaan narkoba diperlukan psikiater atau ahli adiksi yang dapat menangani masalah ketergantungan narkoba. Sebagaimana pecandu lain, pecandu narkoba seringkali menyangkal kondisinya dan sulit diminta untuk melakukan rehabilitasi. Biasanya dibutuhkan intervensi dari keluarga atau teman untuk memotivasi dan mendorong pengguna narkoba untuk mau menjalani rehabilitasi.

1) Pengobatan medis

Penanganan dengan obat-obatan akan dilakukan dalam pengawasan dokter, tergantung dari jenis narkoba yang digunakan. Pengguna narkoba jenis heroin atau morfin, akan diberikan terapi obat seperti methadone. Obat ini akan membantu mengurangi keinginan memakai narkoba.

Obat jenis lain yang dapat digunakan untuk membantu rehabilitasi narkoba, adalah naltrexone.
Namun, obat ini memiliki beberapa efek samping dan hanya diberikan pada pasien rawat jalan, setelah ia menerima pengobatan detoksifikasi. Naltrexone akan menghalangi efek narkoba berupa perasaan senang, bahagia, sehat, dan meredanya rasa sakit, serta mengurangi keinginan untuk mengonsumsi narkoba.

2) Konseling

Konseling merupakan bagian penting dalam mengobati penyalahgunaan narkoba. Konseling yang dilakukan oleh konselor terhadap pengguna narkoba dalam rehabilitasi akan membantu si pengguna mengenali masalah atau perilaku yang memicu ketergantungan tersebut. Konseling biasanya dilakukan secara individu. Meski demikian, tak tertutup kemungkinan untuk melakukan konseling secara berkelompok.

Konseling bertujuan untuk membantu program pemulihan, seperti memulai kembali perilaku hidup sehat ataupun strategi menghadapi situasi yang berisiko penggunaan narkoba 


\section{7 | Jurnal Idea Hukum}

Vol. $6 \mathrm{No} .2$ Oktober 2020

Magister Hukum Universitas Jenderal Soedirman

kembali terulang. Konselor bertanggung jawab untuk memahami bagaimana kecanduan narkoba pada seseorang secara keseluruhan, sekaligus memahami lingkungan sosial yang ada di sekitarnya untuk mencegah terulangnya penyalahgunaan narkoba.

Penanganan untuk mengatasi dampak ketergantungan narkoba perlu melibatkan berbagai aspek lainnya, seperti aspek sosial dan dukungan moral dari orang terdekat dan lingkungan sekitar. Tak jarang pecandu narkoba dapat kembali beraktivitas normal dan menjalani hidup dengan lebih baik setelah menjalani penanganan medis, ditambah dukungan moral dan sosial yang baik.

Bantuan rehabilitasi bagi para pecandu narkotika dan korban penyalahgunaan narkoba di Indonesia merujuk pada Peraturan Bersama tentang Penanganan Pecandu Narkotika dan Korban Penyalahgunaan Narkotika ke dalam Lembaga Rehabilitasi yang diterbitkan pada tahun 2014. Bantuan rehabilitasi juga merujuk pada Undang-Undang No. 35 tahun 2009 tentang Narkotika dan Peraturan Pemerintah No. 25 tahun 2011. Kedua peraturan ini memastikan para pengguna narkoba mendapatkan layanan rehabilitasi yang diperlukan dan tidak lagi ditempatkan sebagai pelaku tindak pidana atau kriminal. Mereka dapat melaporkan diri pada Institusi Penerima Wajib Lapor (IPWL) resmi yang tersebar di seluruh Indonesia, yang terdiri dari Rumah Sakit, Puskesmas, serta Lembaga Rehabilitasi Medis, baik milik pemerintah atau swasta. Sejak diresmikan pada tahun 2011, kini jumlah IPWL di seluruh Indonesia sudah mencapai 274 institusi. Seluruh IPWL yang tersedia memiliki kemampuan melakukan rehabilitasi medis, termasuk terapi untuk menangani gejala, program detoksifikasi, terapi penyakit komplikasi, maupun konseling. Sedangkan IPWL berbasis rumah sakit, juga dapat memberikan rehabilitasi 
medis yang memerlukan rawat inap. ${ }^{18}$

Ada tiga tahap rehabilitasi narkoba yang harus dijalani, yaitu:

(1) Rawat inap kodisi kecanduan yang sangat tidak mungkin untuk dilakukan rawat jalan factor penyalahgunan dan pecandunya yang terlalu lama Yang di biayai oleh Negara

RSUD Gunung Jati Cirebon dan Yayasan Bina Insan Mandiri selama 90 hari akan diobatin, di beri ilmu agama serta belajar bahasa inggris serta didik disiplin dalam kehidupan sehari-hari berpakaian rapih apabila lebih dari 90 hari maka biaya rehabilitasi akan di tanggung oleh keluaraga pelaku yang menjalangkan rehabilitasi dan kondisinya trus di awasi oleh dokter rehabilitasi.

(2) Pascarehab dimana pelaku penyalahgunaan akan menjalani

${ }^{18}$ Wawancara dengan Bapak llyas Kepala Seksi Rehabilitasi BNN Kota Cirebon, hari Rabu, 28 November 2018, Pukul 10.00 WIB di Kantor Badan Narkotika Nasional Kota Cirebon. kehidupan sehari-hari seperti biasa yang

dilakukan oleh

masyarakat pada

umumnya dan di

berikan pelatihan-

pelatihan dan menjalani

selama 50 hari di rumah

damping ketika dokter

rehabilitasi menyatakan

sudah bias di

kembalikan

keluarganya.

(3) Rawat lanjut sendiri dengan dikembalikan kekeluaarganya dan akan di pantau melalui via tetfon dan visit kunjungan selama 6 bulan dan akan bergaualdengaan lingkungan itu sendiri akan tetapi dengan pengawasan dokter rehab. $^{19}$

Badan Narkotika Nasional adalah lembaga pemerintahan nonkementerian yang berkedudukan di bawah Presiden dan bertanggung jawab kepada Presiden. Badan Narkotika Nasional sebagai lembaga independen diharapkan dapat bekerja lebih baik serta transparan

\footnotetext{
${ }^{19}$ Wawancara dengan Bapak Ilyas Kepala Seksi Rehabilitasi BNN Kota Cirebon, hari Rabu, 28 November 2018, Pukul 10.00 WIB di Kantor Badan Narkotika Nasional Kota Cirebon.
} 
39 | Jurnal Idea Hukum

Vol. $6 \mathrm{No} .20 \mathrm{ktober} 2020$

Magister Hukum Universitas Jenderal Soedirman

dan akuntabel dalam menumpas kejahatan Narkotika. Badan Narkotika Nasional juga diharapkan dapat optimal dalam memberikan perlindungan kepada masyarakat dan meningkatkan kerja sama internasonal agar jaringan narkotika transnasional dapat dihancurkan. ${ }^{20}$

Peran Badan Narkotika Nasional jika dikaitkan dengan pencegahan tindak pidana narkotika adalah suatu realitas yang tidak mungkin dilepaskan, sesuai dengan Peraturan Presiden Nomor 23 Tahun 2010 tentang Badan Narkotika Nasional:

1) Menyusun dan melaksanakan kebijakan nasional mengenai

pencegahan dan pemberantasan penyalahgunaan dan peredaran gelap narkotika dan prekursor narkotika. ${ }^{21}$

2) Mencegah dan memberantas penyalahgunaan dan peredaran gelap narkotika dan prekursor narkotika.

3) Berkoordinasi dengan kepala kepolisian republik negara indonesia dalam pencegahan dan pemberantasan penyalahgunaan

dan

${ }^{20}$ Lihat Pasal 64 ayat (2) Undang-Undang No. 35 Tahun 2009 tentang Narkotika.

${ }^{21}$ Lihat Pasal 2 Peraturan Presiden No. 23 Tahun 2010 tentang Badan Narkotika Nasional. peredaran gelap narkotika dan prekursor narkotika.

4) Meningkatkan kemampuan lembaga rehabilitasi medis dan rehabilitasi sosial pecandu narkotika, baik yang diselenggarakan oleh pemerintah maupun masyarakat.

5) Memberdayakan masyarakat dalam pencegahan penyalahgunaan dan peredaran gelap narkotika dan prekursor narkotika.

6) Memantau, mengarahkan, dan meningkatkan kegiatan masyarakat dalam pencegahan penyalahgunaan dan peredaran gelap narkotika dan prekursor narkotika.

7) Melakukan kerja sama bilateral dan multilateral, baik regional maupun internasional, guna mencegah dan memberantas peredaran gelap narkotika dan prekursor narkotika.

8) Mengembangkan laboratorium narkotika dan prekursor narkotika.

9) Melaksanakan administrasi penyelidikan dan penyidikan tehadap perkara penyalahgunaan dan 
peredaran gelap narkotika dan prekursor narkotika.

10) Membuat laporan tahunan mengenai pelaksanaan tugas dan wewenang. ${ }^{22}$

Peran Badan Narkotika Nasional dalam setiap bentuk tindakan ini nantinya akan menekan tingginya tingkat kejahatan yang terjadi, karena setiap kejahatan merupakan tindakan yang sangat merugikan bagi semua orang sehingga dibutuhkan keseriusan dalam menangani setiap bentuk kejahatan yang berlaku. Pelaku kejahatan harus merasakan dampak yang ditimbulkan atas perbuatannya, maka untuk itu setiap perbuatan yang melawan hukum harus dikenai sanksi yang tegas.

Terkait dengan efektivitas Badan Narkotika Nasional dalam melakukan rehabilitasi terhadap pelaku penyalahgunaan narkotika dalam hal ini sudah efektif. Hal tersebut karena dilakukan adanya sebuah keberhasilan Badan Narkotika Nasional dalam pencapaian sasaran terhadap pelaku penyalahgunaan narkotika. Namun efektivitas bekerjanya Badan Narkotika Nasional dalam melakukan

${ }^{22}$ Lihat Pasal 2 Peraturan Presiden No. 23 Tahun 2010 tentang Badan Narkotika Nasional. rehabilitasi terhadap pelaku penyalahgunaan narkotika di Kota Cirebon, terdapat beberapa hambatan diantaranya yaitu:

1) Saat tertangkap tangan kondisi si pelaku dalam keadaan pengaruh obat atau narkotika sehingga menghambat waktu penyidikan.

$\begin{array}{ll}\text { Pengaruh obat obatan } \\ \text { atau narkotika sangat } \\ \text { berbahaya bagi } & \text { tubuh. }\end{array}$
Dampak yang di timbulkan beraneka ragam mulai dari depresi, berhalusinasi, sampai berkhayal hal yang menurutnya pengguna atau pecandu narkotika menjadi tenang, aman, dan nyaman. penyalahgunaan narkotiba yang dalam pengaruh obatobatan atau narkotika sangatlah susah untuk dimintai keterangan atau menceritakan kejadian yg dia lakukan. Pelaku masih dalam pengaruh obat dan sering berkhayal atau berhalusinasi bahwa dia sedang melakukan hal sesuatu yang membuatnya tersenyum sendiri bahkan sering juga merasa depresi dan berdiam diri saat dilakukannya pemeriksaan. Dalam keadaan seperti inilah yang menghambat dalam 
41 | Jurnal Idea Hukum

Vol. $6 \mathrm{No} .20 \mathrm{ktober} 2020$

Magister Hukum Universitas Jenderal Soedirman

melakukan

proses

pemeriksaan yang sedangkan

kondisi si pelaku dalam

pengaruh obat atau pengaruh narkotika. $^{23}$

2) Susah untuk mengatakan kebenaran saat dilakukan pemeriksaan (Plinplan).

3) Pengaruh narkotika sangat berpengaruh penting terhadap kerja syaraf otak.

Pengaruh seperti ini akan menimbulkan si pelaku penyalahgunaan narkotika akan berkata-kata kalimat yang susah dipahami kebenaran, karena dalam kondisi seperti ini si pelaku penyalahgunaan merasa dirinya berhalusinasi jadi setiap kata-kata yang dia ucapkan akan berbeda-beda setiap pertanyaan yang ditanyakan ke si pelaku tersebut. Selain itu ada juga keadaan si pelaku yang mengatakan katakan yang tidak jelas seperti dia sedang berbicara tapi tidak bisa di mengerti. Keadaan yang seperti ini akan menimbulkan seolah-olah pelaku penyahgunaan narkotika ini memiliki dunianya sendiri.

${ }^{23}$ Wawancara dengan Bapak llyas Kepala Seksi Rehabilitasi BNN Kota Cirebon, hari Rabu, 28 November 2018, Pukul 10.00 WIB di Kantor Badan Narkotika Nasional Kota Cirebon.
4) Terbatasnya sarana dan prasarana rehabilitasi bagi pecandu narkotika.

Pelaku penyalahgunaan narkotika semakin banyak, pertahunnya semakin banyak para korban penyalahgunaan dan diantaranya banyak membutuhkan rehabilitasi bagi para pecandu. Keterbatasan sarana yang ada masih minim untuk melakukan pengobatan secara medis, khususnya tempat yang di gunakan untuk rehabilitasi masihlah terbatas, dan para ahli medis sangatlah minim sehingga penanganan korban sedikit terhambat sedangkan korban narkotika semakin bertambah.

Selain keterbatasan
sarana juga keterbatasan
prasarana yaitu minimnya para
pelapor penyalahgunaan narkotika baik itu pengguna atau tidak pengguna yang anggota keluarganya menjadi pengguna bahkan pengedar narkotika. Padahal apabila ada anggota keluarga yang bisa melapor itu akan membantu Badan Narkotika Nasional. ${ }^{24}$

Upaya penerapan rehabilitasi dilakukan oleh

\footnotetext{
${ }^{24}$ Wawancara dengan Bapak llyas Kepala Seksi Rehabilitasi BNN Kota Cirebon, hari Rabu, 28 November 2018, Pukul 10.00 WIB di Kantor Badan Narkotika Nasional Kota Cirebon.
} 


$\begin{array}{lr}\begin{array}{l}\text { Pemerintah } \\ \text { pengguna }\end{array} & \begin{array}{r}\text { terhadap } \\ \text { narkotika }\end{array} \\ \text { berdasarkan Pasal } & 54 \text { Juncto } \\ \text { Pasal } 55 \text { Undang-Undang } \\ \text { Nomor } 35 \text { Tahun } 2009 \\ \text { Tentang Narkotika adalah } \\ \text { dengan melakukan berbagai } \\ \text { tindakan guna mencegah } \\ \text { penyalahgunaan narkotika } \\ \text { yaitu dengan cara: }\end{array}$

1) Rehabilitasi medis pasal 1 angka 16 adalah suatu proses kegiatan pengobatan secara terpadu untuk membebaskan

pecandu dari ketergantungan narkotika. Rehabilitasi medis dilakukan dirumah sakit yang di tunjuk menteri. Lembaga rehabilitasi,dapat melakukan rehabilitasi dengan persetujuan

2) Rehabilitasi sosial pasal 1 angka 17 adalah suatu proses kegiatan pemulihan secara terpadu, agar bekas pecandu narkotika dapat kembali melaksanakan fungsi sosial dalam kehidupan masyarakat.
Rehabilitasi sosial, agar bekas pecandu narkotika dapat di selengarakan oleh pemerintah maupun masyarakat rehabilitasi sosial ini, termasuk melalui pendekatan keagamaan, tradisional, dan pendekatan alternatif lainnya. ${ }^{25}$

Upaya rehabilitasi pecandu narkotika dan korban penyalahgunaan narkotika merupakan hal yang wajib $d a n$ seharusnya lebih diutamakan. Begitu pentingnya rehabilitasi sebagai upaya pemulihan keadaan seharusnya menjadi perhatian khusus dalam menangani tindak pidana narkotika, pasalnya, kita ketahui di sini bahwa ada narkotika yang mengandung zat yang dapat membuat seseorang ketergantungan, dan tentunya hal ini tidak dapat diselesaikan hanya dengan pidana penjara. Perlu adanya rehabilitasi bagi si pelaku agar tidak mengulangi perbuatannya lagi baik karena sengaja atau karena (Perlindungan Korban dan Saksi). Jakarta: Sinar Grafika, hlm. 127. 
43 | Jurnal Idea Hukum

Vol. $6 \mathrm{No} .2$ Oktober 2020

Magister Hukum Universitas Jenderal Soedirman

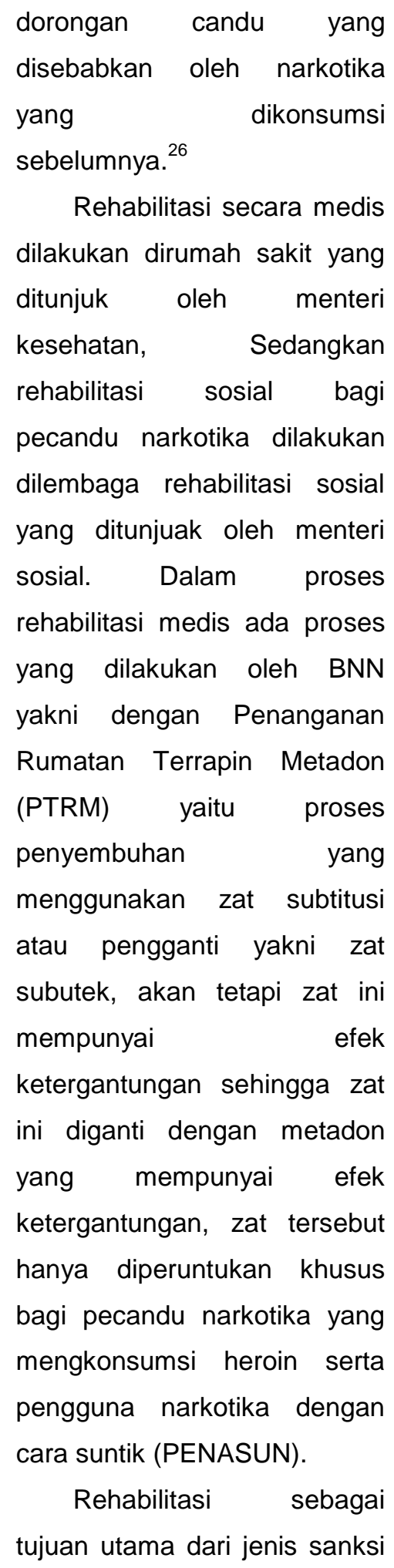

${ }^{26}$ Siswanto S. 2012. Politik Hukum Dalam Undang-Undang Narkotika. Jakarta: Rineka Cipta, hlm. 83. tindakan memiliki keistimewaan dari segi proses resosialisasi pelaku, sehingga diharapkan dapat memulihkan kualitas sosial dan moral seseorang agar dapat berintergrasi lagi dalam masyarakat. Kesetaraan kedudukan sanksi pidana dan sanksi tindakan sangat bermanfaat untuk memaksimalkan penggunaan kedua jenis sanksi tersebut secara proporsional. ${ }^{27}$

Sedangkan rehabilitasi sosial adalah proses pengembalian kebiasaan pecandu narkotika ke dalam kehidupan masyarakat agar seorang pecandu narkotika tidak mengulangi perbuatannya kembali, rehabilitasi sosial juga bertujuan mengintergrasikan kembali pecandu dan/atau penyalahguna narkotika ke dalam masyarakat dengan cara memulihkan proses berpikir, beremosi, dan berperilaku sebagai indikator perbuahan guna memenuhi komponen berkepribadian normal dan agar mampu

${ }^{27}$ Wawancara dengan Bapak Ilyas Kepala Seksi Rehabilitasi BNN Kota Cirebon, hari Rabu, 28 November 2018, Pukul 10.00 WIB di Kantor Badan Narkotika Nasional Kota Cirebon. 

berinteraksi dilingkungan
sosialnya (dalam lingkungan
rehabilitasi).

Pentingnya rehabilitasi pada aspek sosial ditinjau dari hak asasi manusia yang mana hak untuk hidup dan bebas dari ancaman bahaya narkotika dimana rehabilitasi dinilai telah berhasil pada tingkat efektivitas dalam upaya mencegah pecandu melakukan penyalahgunaan narkotika, Sehingga menurut peneliti dalam hal ini hakim harus mempertimbangkan seseorang yang terjerat kasus narkotika dimana dalam putusannya juga harus mempertimbangkan upaya rehabilitasi terhadap orang yang telah ditetapkan sebagai pecandu narkotika agar nantinya seorang pecandu narkotika dapat pulih dari kebiasaan buruk tersebut dan dapat kembali menjalankan aktivitas seperti dulu serta diterima kembali di lingkungan masyarakat. ${ }^{28}$

Rehabilitasi dijadikan sebagai upaya depenalisasi bagi pecandu narkotika guna mengoptimalkan sanksi yang

${ }^{28}$ Wawancara dengan Bapak llyas Kepala Seksi Rehabilitasi BNN Kota Cirebon, hari Rabu, 28 November 2018, Pukul 10.00 WIB di Kantor Badan Narkotika Nasional Kota Cirebon. selama ini belum efektif dalam mencegah dan menanggulangi penyalahgunaan narkotika, sehingga satu-satunya jalan untuk menyembuhkannya adalah dengan mengharuskan menjalani rehabilitasi baik secara medis maupun rehabilitasi secara sosial sebagaimana diatur dalam Undang-Undang Nomor 35 Tahun 2009 tentang Narkotika dan putusan rehabilitasi adalah hak yang harus diupayakan bagi pecandu narkotika. Sebab pecandu narkotika selain sebagai pelaku tindak pidana narkotika juga sebagai korban atas tindak pidana yang dilakukannya sendiri dimana pertimbangan hakim dalam memutus perkara narkotika harus menentukan apakah seorang terdakwa itu telah mengalami ketergantungan terhadap narkotika atau tidak, sehingga perlu dilakukan pemeriksaan oleh dokter atau ahli dalam hal ini tim assement. Disamping itu hakim juga harus membuktikan dari semua keterangan atau fakta-fakta yang diberikan oleh terdakwa, saksi-saksi ataupun Jaksa Penuntut Umum. Jika 
45 | Jurnal Idea Hukum

Vol. $6 \mathrm{No} .2$ Oktober 2020

Magister Hukum Universitas Jenderal Soedirman

terdakwa terbukti sebagai orang yang sudah mengalami ketergantungan, maka baginya berhak mendapat rehabilitasi di panti rehabilitasi.

Pengaturan mengenai penggunaan narkotika saat ini, sudah sesuai dengan ketentuan yang lebih tinggi yakni ketentuan dalam Undang-undang Dasar Negara Republik Indonesia Tahun 1945 yang memberikan hak asasi bagi setiap orang untuk mendapatkan lingkungan yang sehat dan pelayanan kesehatan yang optimal sebagaimana yang diatur dalam Pasal $28 \mathrm{H}$ ayat (1) Undang-undang Dasar Negara Republik Indonesia Tahun 1945 yang menyatakan:

Setiap orang berhak hidup sejahtera lahir dan batin, bertempat tinggal, dan mendapatkan lingkungan hidup yang baik dan sehat serta berhak memperoleh pelayanan kesehatan.

Narkotika merupakan zat atau obat yang sangat bermanfaat dan diperlukan untuk pengobatan penyakit tertentu. Namun jika disalahgunakan atau digunakan tidak sesuai dengan standar pengobatan dapat menimbulkan akibat yang sangat merugikan bagi perorangan atau masyarakat khususnya generasi muda. Hal ini akan lebih merugikan jika, disertai dengan penyalahgunaan dan perdaran gelap narkotika yang dapat mengakibatkan bahaya yang lebih besar bagi kehidupan dan nilainilai budaya bangsa yang pada akhirnya akan dapat melemahkan ketahanan nasional. $^{29}$

Rehabilitasi adalah upaya memulihkan dan mengembalikan kondisi para mantan penyalahguna/ketegantungan NAZA kembali sehat dalam arti sehat fisik, psikologik, sosial dan spiritual/agama (keimanan). Dengan konsisi sehat tersebut diharapkan mereka akan mampu kembali berfungsi secara wajar dalam kehidupannya sehati-hari bauik di rumah, di sekolah/kampus, di tempat kerja dan di lingkungan sosialnya. ${ }^{30}$

Dalam Undang-undang Nomor 35 Tahun 2009 Tentang Narkotika diatur tentang pengobatan dan rehabilitasi. pecandu dan korban penyalahgunaan narkotika tidak lagi diberikan kebebasan untuk sembuh, karena sudah ada

${ }^{29}$ Kaka Alvian Nasution. 2014. Himpunan Lengkap Undang-Undang Narkotika dan Psikotropika. Jogyakarta: Suafa, hlm 154

${ }^{30}$ Siswanto Sunarsono. Op.Cit., hlm. 10. 
ketentuan yang mengaturnya dengan kesadarans sendiri atau keluarganya untuk melaporkan dan atau merehabilitasi para pelaku penyalahguna yang kecanduan.

Melakukan rehabilitasi bagi para penyalahguna narkotika adalah untuk menempatkan para pengguna narkotika baik yang bersalah maupun tidak bersalah menjalani dan atau perawatan melalui rehabilitasi. Hakim selaku penegak hukum juga diberi wewenang untuk menjatuhkan putusan pada penyalahguna yang tidak bersalah melakukan tindak pidana narkotika untuk tetap menjalani pengobatan dan rehabilitasi.

Undang-undang Nomor 35 Tahun 2009 tentang Narkotika juga memuat Pasal 54 yang mengatur tentang rehabilitasi. Pasal 54 yang berbunyi "pecandu narkotika dan korban penyalahgunaan narkotika wajib menjalani rehabilitasi medis dan rehabilitasi sosial. ${ }^{31}$

Dalam Undang-Undang Nomor 35 Tahun 2009 Tentang Narkotika instansi yang berwenang melakukan proses rehabilitasi adalah BNN (Badan Narkotika Nasional) yang sudah

${ }^{31}$ Undang-Undang Nomor 35 Tahun 2009 tentang Narkotika. diatur dalam Pasal 70 sampai

Pasal 72 meiliki tugas dan

wewenang sebagai berikut :

\section{Pasal 70}

BNN mempunyai tugas:

(1) Menyusun dan melaksanakan kebijakan nasional mengenai pemcegahan dan pemberantasan penyalahgunaan dan peredaran gelap Narkotika dan Prekursor Narkotika.

(2) Mencegah dan memberantas penyalahgunaan dan peredaran gelap Narkotika dan Prekursor Narkotika.

(3) Berkoordinasi dengan Kepala kepolisisan Negara Republik Indonesia dalam pencegahan dan pemberantasan penyalahgunaan dan peredaran gelap Narkotika dan Prekursor Narkotika.

(4) Meningkatkan kemampuan lembaga rehabilitasi medis dan rehabilitasi sosial pecandu Narkotika, baik yang diselenggarakan oleh pemerintah maupun masyarakat.

(5) Memberdayakan masyarakat dalam rangka pencegahan, penyalahgunaan dan peredaran gelap Narkotika dan Prekursor Narkotika.

(6) Memantau, mengarahkan, dan meningkatkan kegiatan masyarakat dalam pencegahan penyalahgunaan dan dan peredaran gelap Narkotika dan Prekursor Narkotika.

(7) Melakukan Kerjasama bilateral dan multirateral baik regional maupun internasional, guna mencegah dan memberantas peredaran gelap Narkotika dan Prekursor Narkotika.

(8) Mengembangkan laboratorium Narkotika dan prekursor Narkotika. 


\section{7 | Jurnal Idea Hukum}

Vol. $6 \mathrm{No} .2$ Oktober 2020

Magister Hukum Universitas Jenderal Soedirman

(9) Melaksanakan administrasi penyelidikan dan penyidikan terhadap perkara penyalahgunaan dan peredaran gelap Narkotika dan Prekursor Narkotika.

(10) Membuat laporan tahanan mengenai pelasanaan tugas dan wewenang.

\section{Pasal 71}

Dalam melaksanakan tugas pemberantasan penyalahgunaan dan perdaran gelap Narkotika dan Prekursor Narkotika,BNN berwenang melakukan penyelidikan dan penyidikan penyalahgunaan dan peredaran gelap Narkotika dan Prekursor Narkotika.

\section{Pasal 72}

BNN (Badan Narkotika Nasional) mempunyai wewenang:

(1) Kewenangan sebagaimana dimaksud dalam Pasal 71 dilaksanakan oleh penyidik BNN.

(2) Penyidik BNN sebagaimana dimaksud pada ayat (1) diangkat dan diberhentikan oleh Kepala BNN.

(3) Ketentuan lebih lanjut mengeni syarat dan tatacara pengangkatan dan pemberhentian penyidik BNN sebagaimana dimaksud pada ayat (2) diatur dengan peraturan kepala BNN. ${ }^{32}$

Upaya yang dilakukan oleh

Badan Narkotika Nasional kota

Cirebon sudah efektiv dalam melakukan rehablitasi baik medis ataupun sosial. Namun dalam hal ini terdapat hambatan dalam melakukan rehabilitasi terhadap

${ }^{32}$ Undang-Undang Nomor 35 Tahun 2009 Tentang Narkotika. pelaku penyalahgunaan narkotika yang diantaranya adalah:

1) Faktor hukum

Undang-undang Nomor

35 Tahun 2009 tentang

Narkotika merupakan dasar hukum dalam upaya

penanggulangan dan pemberantasan tindak pidana narkotika. Diundangkannya Undang-Undang Nomor 35 Tahun 2009 tentang Narkotika menggantikan UndangUndang Nomor 22 Tahun 1997 tentang Narkotika menunjukkan adanya upayaupaya ke arah pembangunan hukum. $^{33}$

Pengaturan mengenai penggunaan narkotika saat ini, sudah sesuai dengan ketentuan yang lebih tinggi yakni ketentuan dalam Undang-undang Dasar Negara Republik Indonesia Tahun 1945 yang memberikan hak asasi bagi setiap orang untuk mendapatkan lingkungan yang sehat dan pelayanan kesehatan yang optimal sebagaimana yang diatur dalam Pasal $28 \mathrm{H}$ ayat (1) Undang-undang Dasar Negara Republik Indonesia

${ }^{33}$ Soerjono Soekanto. 2008. Faktor-Faktor yang Mempengaruhi Penegak Hukum. Jakarta: Rajawali Press, hlm. 67. 
Tahun $1945 \quad$ yang

menyatakan:

Setiap orang berhak hidup sejahtera lahir dan batin, bertempat tinggal, dan mendapatkan lingkungan hidup yang baik dan sehat serta berhak memperoleh pelayanan kesehatan.

2) Faktor penegak hukum

Dalam upaya Program Pencegahan dan

Pemberantasan

Penyalahgunaan dan

Peredaran Gelap Narkoba (P4GN) di Cirebon tentunya membutuhkan kualitas dan kuantitas dari petugas yang memadai. Kualitas yang baik tentunya berguna untuk mentrasformasikan amanah yang terkandung dalam undang-undang dalam bentuk pelaksanaan lapangan atau penerapan. Sedangkan kuantitas berguna untuk memaksimalkan penerapan atau pelaksanaan dari tugas dan wewenang BNN (Badan Narkotika Nasional).

Secara umum, faktor yang mempengaruhi pelaksanaan fungsi suatu perundang-undangan adalah profesional dan optimal pelaksanaan peran, wewenang dan fungsi dari penegak hukum baik di dalam menjalankan tugas yang

dibebankan terhadap diri

mereka atau dalam

menegakan peraturan

perundang-undangan

tersebut.Di mana seseorang menaati ketentuan perundangundangan adalah karena terpenuhinya suatu kepentingannya (interest) oleh perundang-undangan tersebut. Kemudian apabila peraturan perundangundangan sudah baik, dan tidak ada persepsi yang sama dalam penegakan hukum, maka akan menimbulkan efek pada sistem penegakan hukum. Aturan yang sudah baik tapi tidak didukung oleh penegak hukum maka cukup sulit untuk mewujudkan penegakan hukum yang efektif. $^{34}$

3) Faktor sarana dan prasarana Tindak pidana Narkotika tidak lagi dilakukan secara perseorangan, melainkan melibatkan banyak orang yang secara bersama-sama, bahkan merupakan suatu sindikat yang terorganisir dengan jaringan yang luas yang bekerja secara rapi dan sangat

\footnotetext{
${ }^{34}$ Wawancara dengan Bapak Adi Purwanto Hakim Pengadilan Negeri Indramayu, hari Selasa, 27 November 2018, Pukul 08.00 WIB di Kantor Pengadilan Negeri Indramayu.
} 
49 | Jurnal Idea Hukum

Vol. $6 \mathrm{No} .2$ Oktober 2020

Magister Hukum Universitas Jenderal Soedirman

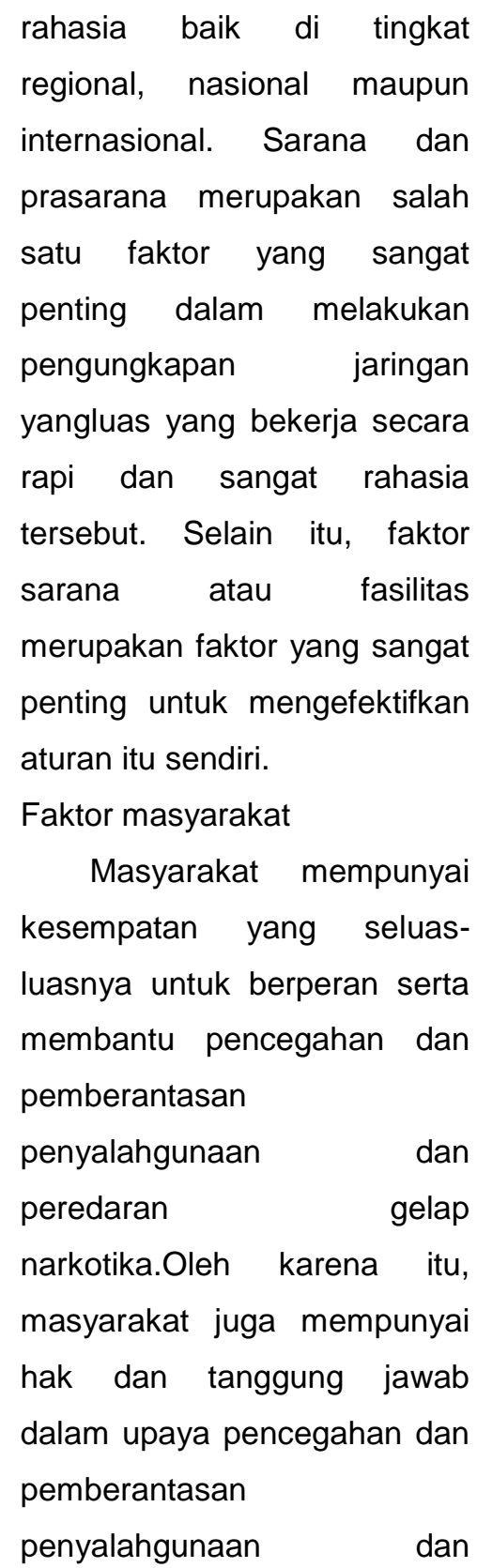

peredaran gelap narkotika.

Dalam Pasal 106 Undangundang Nomor 35 Tahun 2009

Tentang narkotika diatur bahwa hak masyarakat dalam upaya pencegahan dan pemberantasan

penyalahgunaan narkotika dan prekursor narkotika diwujdkan dalam bentuk:

(1) Mencari, memperoleh dan memberikan informasi adanya dugaan telah terjadi tindak pidana narkotika dan prekursor narkotika.

(2) Memperoleh pelayanan dalam mencari, memperoleh dan memberikan informasi tentang adanya dugaan telah terjadi tindak pidana nerkotika dan prekursor narkotika kepada penegak hukum atau BNN yang menangani perkara tindak pidana narkotika dan prekursornarkotika.

(3) Memperoleh jawaban atas pertanyaan tentang laporannya yang diberikan kepada penegak hukum atau BNN.

(4) Memperoleh perlindungan hukum pada saat atau diminta hadir dalam proses peradilan. ${ }^{35}$ 


\section{Simpulan dan Saran}

\section{a. Simpulan}

Dari hasil penelitian yang dilakukan dilapangan yang telah diuraikan dalam pembahasan penelitian, maka penulis dapat menyimpulkan bahwa:

1) Bentuk upaya rehabilitasi Badan Narkotika Nasional Kota Cirebon dalam melakukan rehabilitasi terhadap pelaku penyalahgunaan narkoba sudah efektif. Hal tersebut dilakukan dengan melakukan pengobatan medis, konseling. rehabilitasi medis, yang dilakukan melalui pendampingan langsung terhadap pelaku penyalahgunaan narkoba yang bertujuan untuk memberikan efek jera terhadap pelaku penyalahgunaan narkoba sebagai bentuk dari sanksi penjatuhan pidana rehabilitasi.

2) Faktor penghambat Badan Narkotika Nasional Kota Cirebon dalam melakukan rehabilitasi terhadap pelaku penyalahgunaan narkoba adalah adanya faktor sarana dan prasarana yang masih kurang memadai seperti masih

November 2018, Pukul 08.00 WIB di Kantor Pengadilan Negeri Indramayu. kurangnya tenaga medis dalam melakukan rehabilitasi terhadap pelaku penyalahgunaan narkoba serta saat tertangkap tangan kondisi si pelaku dalam keadaan pengaruh obat atau narkotika sehingga menghambat waktu dalam penyidikan.

b. Saran

1. Badan Narkotika Nasional Kota Cirebon haruslah lebih sering mengadakan sosialisasi dan penyuluhan tentang cara mencegah dengan menitikberatkan pada pembinaan moral, membina kekuatan mental masyarakat dan remaja.

2. Penegak hukum harus sering mengadakan patroli-patroli menyeluruh di Kota Cirebon baik di daerah pelabuhan, bandara udara, dan zona-zona bebas lainya. Selain itu juga dilakukan dengan memperluas lingkup pengawasan atas wilayah udara dan daerahdaerah terpencil agar dapat melindungi masyarakat terhadap kegiatan jahat yang dilakukan oleh pengedar narkotika.

3. Masyarakat harus lebih aktif dalam mencari, memperoleh dan memberikan informasi 


\section{1 | Jurnal Idea Hukum}

Vol. $6 \mathrm{No} .2$ Oktober 2020

Magister Hukum Universitas Jenderal Soedirman

adanya dugaan telah terjadi

tindak pidana narkotika dan

prekursor narkotika.

\section{DAFTAR PUSTAKA}

Anonim. Peraturan Presiden Republik Indonesia Nomor 23 tahun 2010 tentang Badan Narkotika Nasional.

Ali. Zainuddin., 2010. Metode Penelitian Hukum. Jakarta: Sinar Grafika.

Brata. Sumadi Surya., 1992. Metode Penelitian. Jakarta: Rajawali Press.

Badan Narkotika Nasional. 2009. Pencegahan Penyalahgunaan Narkoba Sejak Dini. Jakarta.

Dirdjosisworo. Soedjono., 1987. Hukum Narkotika Indonesia. Bandung: Alumni.

Didik M. Arief Mansur dan Elisatris Gultom. 2007. Urgensi Perlindungan Korban Kejahatan. Jakarta: PT. Raja Grafindo Persada.

Makarao. M. Taufik., 2003. Tindak Pidana Narkotika. Jakarta: Ghalia Indonesia.

Muntaha. Aspek Yuridis Penyalahgunaan Narkotika di kalangan Remaja. Jurnal Mimbar Hukum, Vol. 23 Nomor 1 Februari 2011, Yogyakarta: Fakultas Hukum Universitas Gadjah Mada.

Marzuki. Peter Mahmud., Penelitian Hukum, Edisi Revisi. Jakarta: Kencana Prenadamedia.

Nasution. Kaka Alvian., 2014. Himpunan Lengkap

Undang-Undang Narkotika dan Psikotropika. Jogyakarta: Suafa.

Sugiyono. 2008. Memahami Penelitian Kualitatif. Bandung: Alfabeta.

Soekanto. Soerjono., 2008. FaktorFaktor yang Mempengaruhi Penegak Hukum. Jakarta: Rajawali Press.

_., 2010. Pengantar Peneliti Hukum. Jakarta: UII Pres.

1986. Penelitian Hukum. Jakarta: Universitas indonesia.

Siswanto. 2012. Politik Hukum dalam Undang-Undang Narkotika. Jakarta: Rineka Cipta.
S. Siswanto., 2012. Politik Hukum Dalam Undang-Undang Narkotika. Jakarta: Rineka Cipta.

Waluyo. Bambang., 2011. Viktimologi (Perlindungan Korban dan Saksi). Jakarta: Sinar Grafika. 1991. Penelitian Hukum dalam Praktek. Jakarta: Sinar Grafika.

Penindakan Hukum harus menjadi Panglima. Http://bnn.go.id., diakses 30 September 2018, Pukul 21.41 WIB.

Zoraya Ralie. 2017. Tahapan dan Proses Raehabilitasi Penyalahgunaan Narkoba. Http://www.google.com., $\quad 30$ September 2018, Pukul 20.00 WIB. 